\title{
Adherence of SARS-CoV-2 delta variant to surgical mask and N95 respirators
}

Ana C. Lorenzo-Leal ${ }^{1}$, Selvarani Vimalanathan ${ }^{1,2}$, Horacio Bach ${ }^{1, *}$

${ }^{1}$ Faculty of Medicine, Division of Infectious Diseases, University of British Columbia, Vancouver,

BC, Canada

${ }^{2}$ Pathology \& Laboratory Medicine, University of British Columbia, Vancouver, BC, Canada.

*Corresponding author: 2660 Oak Street, University of British Columbia, Vancouver, BC, V6H 3Z6, Canada. Phone: 1-604-875-4111 x 62107.Email: hbach@mail.ubc.ca 
medRxiv preprint doi: https://doi.org/10.1101/2022.01.05.22268808; this version posted January 6, 2022. The copyright holder for this preprint (which was not certified by peer review) is the author/funder, who has granted medRxiv a license to display the preprint in perpetuity.

All rights reserved. No reuse allowed without permission.

\begin{abstract}
The use of facial protection, including masks and respirators, has been adopted globally due to the COVID-19 pandemic. These products have been demonstrated to be effective in reducing the transmission of the virus. To determine whether or not the virus adheres to masks and respirators, we dissected four respirators and one surgical mask into layers. These individual layers were contaminated with the SARS-CoV-2 delta variant, and its release by vortexing was performed. Samples were used to infect Vero cells, and a plaque assay was used to determine to evaluate the adherence of the virus. Results showed that a cumulative log reduction of the layers reduced the load of the virus six-folds. Our study confirms the effectiveness of facial protection in reducing the transmission and or infection of the virus.
\end{abstract}

Keywords: surgical masks, respirators, SARS-CoV-2, COVID-19, adherence 
medRxiv preprint doi: https://doi.org/10.1101/2022.01.05.22268808; this version posted January 6, 2022. The copyright holder for this preprint (which was not certified by peer review) is the author/funder, who has granted medRxiv a license to display the preprint in perpetuity.

\section{Introduction}

The pandemic of the novel coronavirus SARS-CoV-2, the causative agent of COVID-19, was initially identified in Wuhan, China, and has spread worldwide. According to the World Health Organization (WHO), as of November $20^{\text {th }}$, 2021, there have been 5,127,696 deaths and 255,324,963 confirmed cases of COVID-19 [1].

COVID-19 disease seems to be spreading through airborne transmission via aerosol, and as it is known that respiratory infections mainly occur when breathing, speaking, sneezing, coughing, or talking occurs. These transmissions are facilitated by droplets ( $>5$ to $10 \mu \mathrm{m})$ and/or aerosols $(\leq 5 \mu \mathrm{m})$ containing the virus SARS-CoV-2 (ref). Aerosol's accumulation, also known as the "gas cloud," could remain infectious for hours in indoor spaces. Thus, the implementation of masks or respirators has a tremendous effect on reducing aerosol transmission [2-5]. This physical protection is in use and has been adopted globally.

There are different types of masks or respirators with various levels of protection, which can be reusable or disposable. Generally, masks do not fit as tightly as respirators. For example, N95 respirators are classified by the U.S. National Institute for Occupational Safety and Health (NIOSH) as air filtration, filtering at least $95 \%$ of airborne particles. N95 respirators and surgical masks are examples of the most common disposable masks, while reusable are mainly industrial masks with half or full facepiece respirators [5].

According to the Centers for Disease Control and Prevention (CDC) and the NIOSH, surgical masks are approved by the Food and Drug Administration (FDA) and intended to use as protection to the wearer against multiple hazardous environments, such as those created by sprays, dangerous fluids, splashes, and droplets. However, masks would not always confer respiratory 
medRxiv preprint doi: https://doi.org/10.1101/2022.01.05.22268808; this version posted January 6, 2022. The copyright holder for this preprint (which was not certified by peer review) is the author/funder, who has granted medRxiv a license to display the preprint in perpetuity.

All rights reserved. No reuse allowed without permission.

protection because of their lower reliable level of filtration against smaller particles that could be inhaled, such as airborne particles.

Surgical masks contain mainly three-layer structures with different functions. For example, the outer layer is repelling water, the middle layer functions as a trap of particles and prevents the penetration of microorganisms, and the inner layer absorbs moisture [2,6].

On the other hand, N95 respirators are defined by NIOSH as a filtration system that retains at least $95 \%$ of different airborne sizes particles (from aerosols to large droplets), reducing the exposure to the user [7]. Respirators may contain extra layers compared to surgical masks. For example, N95 respirators have between three to five layers, comprising an inner and outer layer, a filter layer, and in some cases, a support layer [6].

The penetration or filtration mechanism of aerosols containing SARS-CoV-2 in masks has been studied and reported in different studies $[2,3,6,8,9]$. Moreover, contamination with SARSCoV-2 on the masks' outer surface has also been reported [10]. Still, a detailed investigation addressing the question of whether or not the virus remains adhered to the layers has not been reported. Then, this study aimed to evaluate the adherence of the SARS-CoV-2 delta variant on different layers of a surgical mask and N95 respirators.

\section{Methods}

\subsection{Virus and cell lines}

SARS-CoV-2 delta variant (B.1.617.2) was provided by the British Columbian Centre for Disease Control Public Health Laboratory, Vancouver, Canada. Vero E6 cells (ATCC CCL-81) were used to replicate the virus and infections. Cells were grown in MEM (Invitrogen) supplemented with 5\% fetal calf serum (Invitrogen), pyruvate, and non-essential amino acids. All 
medRxiv preprint doi: https://doi.org/10.1101/2022.01.05.22268808; this version posted January 6, 2022. The copyright holder for this preprint (which was not certified by peer review) is the author/funder, who has granted medRxiv a license to display the preprint in perpetuity.

All rights reserved. No reuse allowed without permission.

the incubations were performed in an incubator at $37^{\circ} \mathrm{C}$ supplemented with $5 \% \mathrm{CO}_{2}$. All the work performed in this study was conducted in level 3 at the Facility for Infectious Disease and Epidemic Research (University of British Columbia, Vancouver, BC, Canada).

Viral stocks were prepared by infecting $80 \%$ confluent Vero E6 cells with $1 \mathrm{~mL}$ of the virus at a $5 \times 10^{5} \mathrm{PFU} / \mathrm{mL}$ concentration. After $72 \mathrm{~h}$, the supernatant was collected and cleared by centrifugation at $3200 \times g$ for $10 \mathrm{~min}$. The supernatant was aliquoted and kept at $-80^{\circ} \mathrm{C}$ until further use. The titer of the virus was determined to be $5.9 \times 10^{5} \mathrm{pfu} / \mathrm{mL}$ by plaque assay.

A plaque assay was performed overnight by dispensing $1.5 \times 10^{5}$ Vero cells into 12 -well plates. The next day, the $80-100 \%$ confluency was verified, and cells were infected with the virus for one h. Then, the virus was washed away, and the monolayer was overlayed with $1.5 \mathrm{~mL}$ of $2 \mathrm{x}$ MEM supplemented with 2\% cellulose (Sigma) (v/v 1:1)

\subsection{Mask or respirators preparation}

Five different masks or respirators (Table 1) were used in this study. Pieces of $1 \mathrm{~cm}^{2}$ were cut, separated into individual layers, decontaminated by submerging the pieces into $70 \%$ ethanol for $10 \mathrm{~min}$, and dry overnight at $37^{\circ} \mathrm{C}$ inside a decontaminated Biosafety Containment Level 2. The decontaminated layers were stored in empty sterile $1.5 \mathrm{~mL}$ tubes until further use.

Table 1. Characteristics of the masks and respirators used in this study

\begin{tabular}{lllc}
\hline Brand & Layer & Material & Reference \\
& & & \\
\hline 1 North N95 7130 (Lot No. 9E001) & Outer & Polypropylene & {$[11]$} \\
Closed-cell vinyl foam & Filter & Polypropylene composite & \\
& Support & Polyester & \\
& Inner & Polyester &
\end{tabular}




\begin{tabular}{|c|c|c|}
\hline 2 North N95 5130 (Lot No. 9G004) & Outer & Polyester \\
\hline Open-cell foam seal & Filter & Polypropylene \\
\hline & Inner & Polyester \\
\hline Three 3-Ply surgical mask & Outer & Fluid resistant \\
\hline & Filter & Polypropylene \\
\hline & Inner & Absorbent \\
\hline 4 3M 8210 N95 (Lot No. A20047) & Outer & Polyester \\
\hline Standard respirator & Filter & Polypropylene \\
\hline & Inner & Polyester \\
\hline 5 3M 1860 N95 (Lot No. B16047) & Outer & Polyester \\
\hline Surgical respirator & Filter & Polypropylene \\
\hline & Inner & Polyester \\
\hline
\end{tabular}
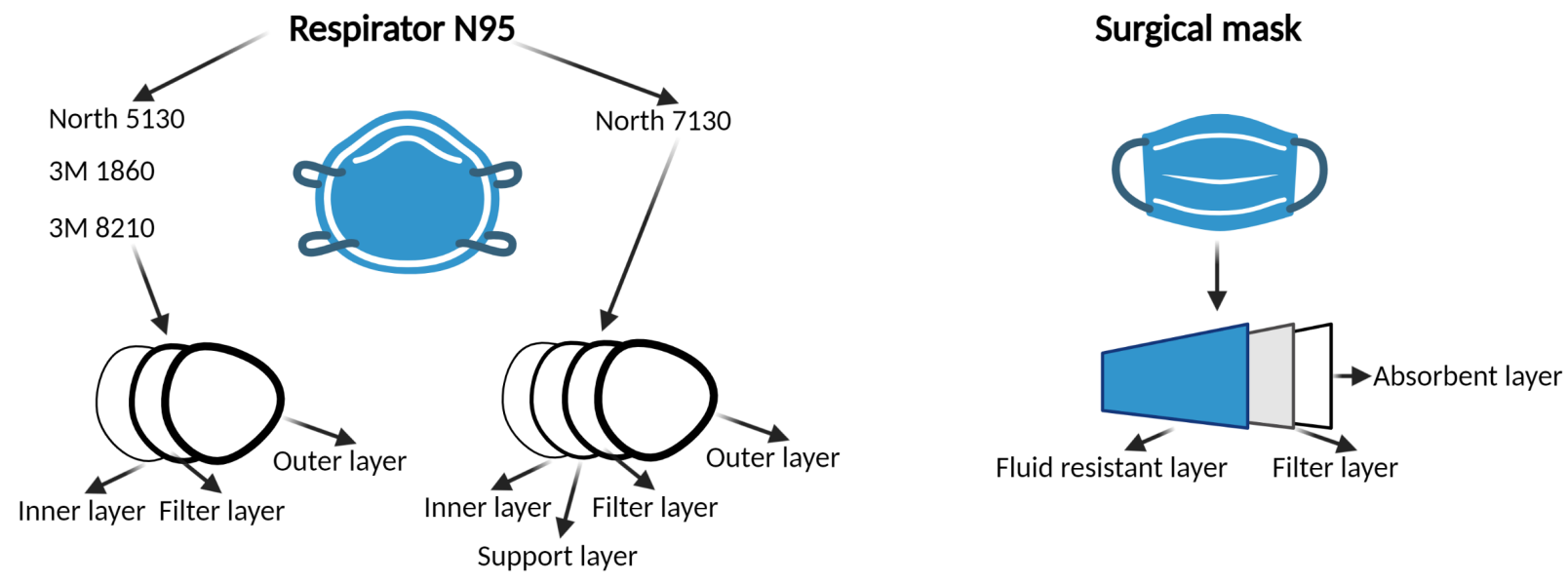

Figure 1. Mask or respirators layers. Description of the mask and respirator layers used in this study. Created by Biorender.com

\subsection{Contamination of layers}

The layers were exposed to $2 \times 10^{3}$ viruses (in $10 \mu \mathrm{L}$ MEM). After 10 min (time to dry the drop), the layers were submerged in $300 \mu \mathrm{L}$ of OptiMEM (Invitrogen) in a $1.5 \mathrm{~mL}$ screw-top tube 
medRxiv preprint doi: https://doi.org/10.1101/2022.01.05.22268808; this version posted January 6, 2022. The copyright holder for this preprint (which was not certified by peer review) is the author/funder, who has granted medRxiv a license to display the preprint in perpetuity. All rights reserved. No reuse allowed without permission.

and vortexed vigorously for 1 min every. The samples were subjected to 10 -fold dilutions using OptiMEM in $1.5 \mathrm{~mL}$ tubes.

\subsection{Plaque assay}

$5.0 \times 10^{5}$ Vero E6 cells in complete MEM were seeded into 12-well cell culture plates (Thermo Scientific) and incubated overnight at $37{ }^{\circ} \mathrm{C}$ supplemented with $5 \% \mathrm{CO}_{2}$. Cells were then checked for confluency, and the medium was removed from the wells. The serial dilutions (300 $\mu \mathrm{L})$ were added to the corresponded wells, and the plates were incubated as explained above. The plates were placed back in the incubator for an hour to allow infection. The plates were gently rocked every $15 \mathrm{~min}$. Then, the virus and the medium were removed from the wells, and an overlay of $2 \%$ cellulose and $2 \mathrm{x}$ complete MEM (as detailed above) was gently added to each well. Plates were incubated for $72 \mathrm{~h}$, fixed for 30 min with $4 \%$-formaldehyde (PFA, J.T. Baker) in PBS. After removing the PFA, the cells were stained with $250 \mu \mathrm{L}$ of $1 \%$ crystal violet (Sigma), dissolved in $20 \%$ methanol (Fisher) for 3,0 min, washed twice with water, dried, and the number of plaques was counted and recorded.

\section{Results and discussion}

The adherence of SARS-CoV-2 to different types of buccal protection showed that all of the layers could retain the virus at different extents. In addition, adherent viruses were not released upon vortexing the samples, suggesting that they are tightly bound to the layers once they are deposited and dried on their surface.

Analysis of the results showed that an accumulation of the log reductions of the layers ranged between 6.15-8.45 (Figure 2). In addition, respirator 2 showed superior retention of the 
virus with an increase of approximately 1-2 log reduction (Figure 2B) compared to the rest of the tested products.
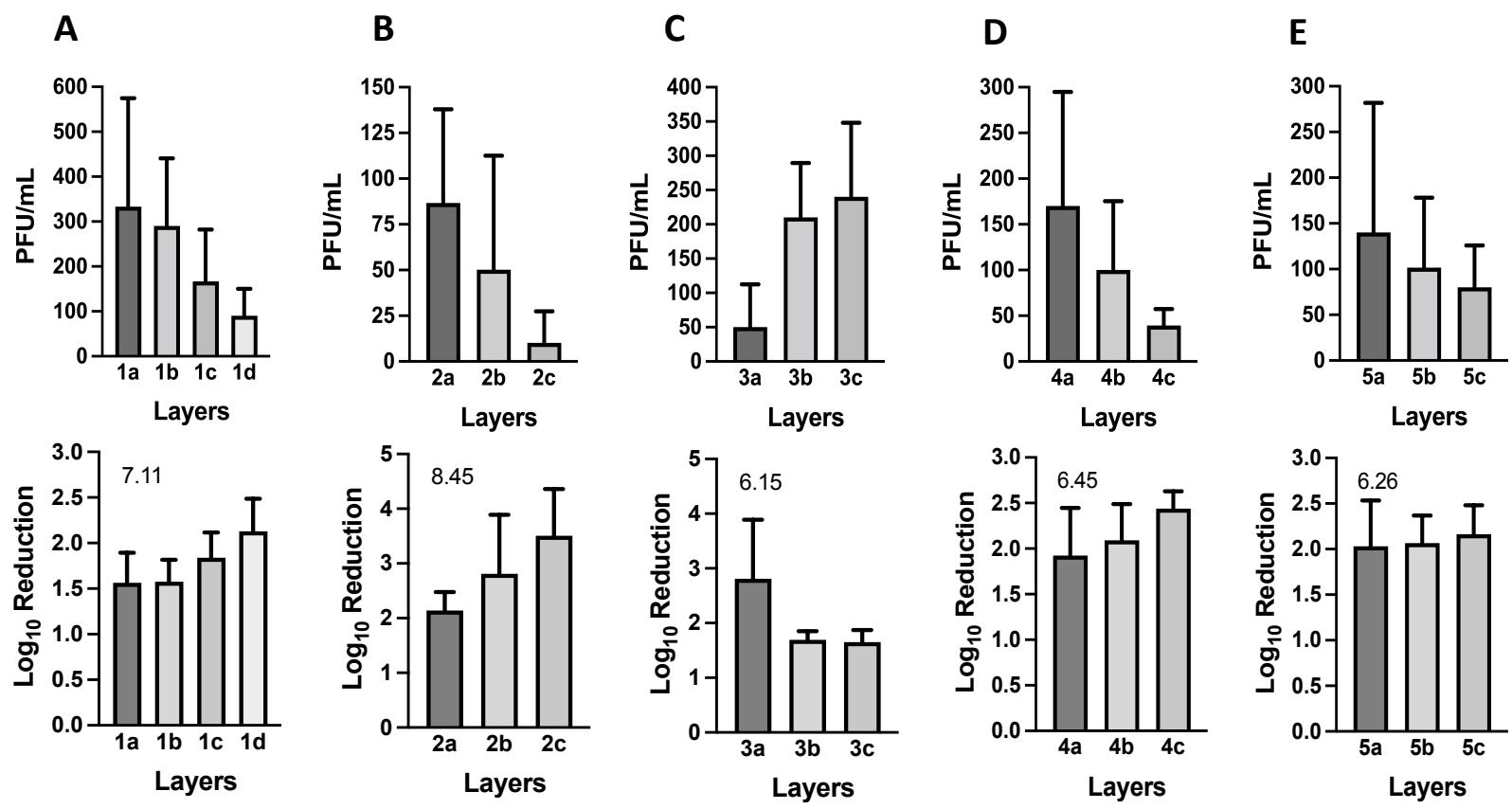

Figure 2. Viral titers of SARS-CoV-2 deposited onto layers. The virus was deposited on the layers, and after drying, non-adherent viruses were released from the layers by vortexing and according to the Method section. (A) Respirator 7130, (B) Respirator 5130, (C) Surgical masks, (D) Respirator 8210, and (E) Respirator 1860. Shown is the mean of at least three independent experiments $\pm \mathrm{SD}$. The number located in the lower panel is the cumulative log reduction of the layers. The arrangement of the layers is from the outer layer (a) to the inner layer (c), except for one that has four layers $(d)$.

People use medical masks as protection from sprays and splashes of fluids by sick people. Although extended usage or reuse of masks has become common, especially during the present pandemics, this could lead to an infection of the person wearing the mask due to the possible presence of pathogens in different layers of the masks [10]. 
medRxiv preprint doi: https://doi.org/10.1101/2022.01.05.22268808; this version posted January 6, 2022. The copyright holder for this preprint (which was not certified by peer review) is the author/funder, who has granted medRxiv a license to display the preprint in perpetuity.

All rights reserved. No reuse allowed without permission.

Masks materials (Table 1) are mainly nonwoven fabric made by a mass of fibers (such as polypropylene, polyester, and polyurethane) bonded by different means such as mechanical, heat or chemical. The efficiency of particle filtration (permeability), bacterial or virus filtration, differential pressure, flammability, flexibility, and resistance to fluids are some of the performance characteristics for materials used in masks $[2,3,6]$. Regarding permeability, when resistance to fluid material is used, aerosols are likely to travel around the mask following contours seeking low resistance areas or leeks, rather than penetration of the filter material [3].

Between the different layers in a mask or respirator, the most important one is the filter layer, which is mainly produced through a melt-blown process, where a polymer (such as polyethylene) is exposed to blows of high-velocity air, forming a web shape of filaments. This filter layer (commonly used in N95 respirators) has an electrostatic charge; therefore, the polymer filtration capability for small particles increases because of electrostatic adsorption [2,14]. In our study, the respirators contained at least one layer of polypropylene, suggesting that an electrostatic layer increased the retention of the virus.

A model of viral retention based on the electrostatic charges on the surface of the virus and the modified polypropylene (electret) might explain one of the reasons for the log reduction of the virus. In the case of the virus, the Spike protein surrounds the viral particle. Assuming that other components of the virus are not contributing to the surface charge of the virus (lipids and nucleocapsid are part of the core of the virus [15], we can attribute the net surface charge of the virus to the Spike protein. This protein looks to have a particular disorder [16] probably because of its interaction with the membrane proteins [17]. Thus, the electrostatic interaction of the virus and the electret is based on the charge of the Spike protein [18]. One of the main variables regarding the isoelectric point of the Spike protein is the large number of ionizable amino acids 
medRxiv preprint doi: https://doi.org/10.1101/2022.01.05.22268808; this version posted January 6, 2022. The copyright holder for this preprint (which was not certified by peer review) is the author/funder, who has granted medRxiv a license to display the preprint in perpetuity. All rights reserved. No reuse allowed without permission.

that contribute to the net charge (e.g., C, D, E, H, K, R, and Y) [15]. Then, the pH will play an important role in the fluctuation of the surface charge at which the virus.

The isoelectric point of the Spike protein is 6.2 [19]. Although this value is lower than the physiological $\mathrm{pH}$ (7.0), most Spike protein is negatively charged [15], except the receptor-binding domain. This receptor is located in the apical portion of the spike protein, and it has been calculated to remain positively charged through a range of $\mathrm{pH}$ values [20]. Interestingly, the positive charge of the receptor-binding domain has increased in the SARS-CoV-2 variants [20] because of the mutation observed in this region.

On the other hand, studies reported negative surface charges on the polypropylene electrets, varying between -200 to -1350 (V) [21,22]. Thus, a strong electrostatic attraction occurs between the receptor-binding domain of the Spike protein and the polypropylene electret, contributing to the retention of the viruses on the layers.

\section{Conclusions}

In this study, we report the adherence of the SARS-CoV-2 delta variant to different buccal protection (mask and respirators). We hypothesize that a strong electrostatic binding occurs, and as a result, the cumulative viral $\log$ reduction is over 6 . Our results also showed that masks and respirators efficiently reduce infections either from the infected (wearer) or the recipient person. 
medRxiv preprint doi: https://doi.org/10.1101/2022.01.05.22268808; this version posted January 6, 2022. The copyright holder for this preprint (which was not certified by peer review) is the author/funder, who has granted medRxiv a license to display the preprint in perpetuity. All rights reserved. No reuse allowed without permission.

Acknowledgement: We thank Dr. Mel Krajden from the British Columbian Centre for Disease Control Public Health Laboratory, Vancouver, Canada for the access to the SARS-CoV-2 delta variant.

Author Contributions: H.B. conceptualized, reviewed, edited the manuscript, and procured financing acquisition. A.L. investigated, wrote, reviewed, and edited the manuscript. S.V. investigated and reviewed the manuscript. All authors have read and agreed to the published version of the manuscript.

Funding: This work was supported by the Canadian Institutes of Health Research (CIHR) grant Canadian 2019 Novel Coronavirus (COVID-19) Rapid Research Funding Opportunity Therapeutics to H.B (No. OV3- 170627).

Conflicts of Interest: The authors have nothing to disclose.

\section{References}

1. World Health Organization WHO Coronavirus (COVID-19) Dashboard Available online: https://covid19.who.int/ (accessed on 11 September 2021).

2. Chua, M.H.; Cheng, W.; Goh, S.S.; Kong, J.; Li, B.; Lim, J.Y.C.; Mao, L.; Wang, S.; Xue, K.; Yang, L.; et al. Face Masks in the New COVID-19 Normal: Materials, Testing, and Perspectives. Research 2020, 2020, 1-40, doi:10.34133/2020/7286735.

3. Hill, W.C.; Hull, M.S.; MacCuspie, R.I. Testing of Commercial Masks and Respirators and Cotton Mask Insert Materials Using SARS-CoV-2 Virion-Sized Particulates: Comparison of Ideal Aerosol Filtration Efficiency versus Fitted Filtration Efficiency. Nano Lett. 2020, 20, 7642-7647, doi:10.1021/acs.nanolett.0c03182.

4. Howard, J.; Huang, A.; Li, Z.; Tufekci, Z.; Zdiamal, V.; van der westhuizen, H.-M.; von Delft, A.; Price, A.; Fridman, L.; Tang, L.-H.; et al. An Evidence Review of Face Masks against COVID-19. 2021, 118, 1-12, doi:https://doi.org/10.1073/pnas.2014564118.

5. Prather, K.A.; Wang, C.C.; Schooley, R.T. Reducing Transmission of SARS-CoV-2. Science 2020, 368, 1422-1424, doi:10.1126/science.abc6197.

6. Tcharkhtchi, A.; Abbasnezhad, N.; Zarbini Seydani, M.; Zirak, N.; Farzaneh, S.; Shirinbayan, M. An Overview of Filtration Efficiency through the Masks: Mechanisms of 
medRxiv preprint doi: https://doi.org/10.1101/2022.01.05.22268808; this version posted January 6, 2022. The copyright holder for this preprint

(which was not certified by peer review) is the author/funder, who has granted medRxiv a license to display the preprint in perpetuity.

All rights reserved. No reuse allowed without permission.

the Aerosols Penetration. Bioact. Mater. 2021, 6, 106-122,

doi:10.1016/j.bioactmat.2020.08.002.

7. CDC Healthcare Workers Available online: https://www.cdc.gov/coronavirus/2019ncov/hcp/respirator-use-faq.html (accessed on 3 November 2021).

8. Konda, A.; Prakash, A.; Moss, G.A.; Schmoldt, M.; Grant, G.D.; Guha, S. Aerosol Filtration Efficiency of Common Fabrics Used in Respiratory Cloth Masks. ACS Nano 2020, 14, 6339-6347, doi:10.1021/acsnano.0c03252.

9. Lustig, S.R.; Biswakarma, J.J.H.; Rana, D.; Tilford, S.H.; Hu, W.; Su, M.; Rosenblatt, M.S. Effectiveness of Common Fabrics to Block Aqueous Aerosols of Virus-like Nanoparticles. ACS Nano 2020, 14, 7651-7658, doi:10.1021/acsnano.0c03972.

10. Chughtai, A.A.; Stelzer-Braid, S.; Rawlinson, W.; Pontivivo, G.; Wang, Q.; Pan, Y.; Zhang, D.; Zhang, Y.; Li, L.; MacIntyre, C.R. Contamination by Respiratory Viruses on Outer Surface of Medical Masks Used by Hospital Healthcare Workers. BMC Infect. Dis. 2019, 19, 491, doi:10.1186/s12879-019-4109-x.

11. Datasheet: Technical Data Sheet Technical Data 7130n95 8140p95 8150p100 North Filtering Facepiece Available online:

http://www.industrycortex.com/datasheets/profile/1259774979/technical-data-sheettechnical-data-7130n95-8140p95-8150p100-nort (accessed on 3 November 2021).

12. Chin, A.W.H.; Chu, J.T.S.; Perera, M.R.A.; Hui, K.P.Y.; Yen, H.-L.; Chan, M.C.W.; Peiris, M.; Poon, L.L.M. Stability of SARS-CoV-2 in Different Environmental Conditions. micro 2020, 1, e10, doi:https://doi.org/10.1016/ S2666-5247(20)30003-3.

13. $3 \mathrm{M}^{\mathrm{TM}}$ Particulate Respirator 8210 , N95 $160 \mathrm{EA} /$ Case Available online: https://www.3m.com/3M/en_US/p/d/v000585997/ (accessed on 3 November 2021).

14. Campos, R.K.; Jin, J.; Rafael, G.H.; Zhao, M.; Liao, L.; Simmons, G.; Chu, S.; Weaver, S.C.; Chiu, W.; Cui, Y. Decontamination of SARS-CoV-2 and Other RNA Viruses from N95 Level Meltblown Polypropylene Fabric Using Heat under Different Humidities. ACS Nano 2020, 14, 14017-14025, doi:10.1021/acsnano.0c06565.

15. Javidpour, L.; Božič, A.; Naji, A.; Podgornik, R. Electrostatic Interactions between the SARS-CoV-2 Virus and a Charged Electret Fibre. Soft Matter 2021, 17, 4296-4303, doi:10.1039/D1SM00232E.

16. Beniac, D.R.; Andonov, A.; Grudeski, E.; Booth, T.F. Architecture of the SARS Coronavirus Prefusion Spike. Nat. Struct. Mol. Biol. 2006, 13, 751-752, doi:10.1038/nsmb1123.

17. Gorbalenya, A.E.; Baker, S.C.; Baric, R.S.; de Groot, R.J.; Drosten, C.; Gulyaeva, A.A.; Haagmans, B.L.; Lauber, C.; Leontovich, A.M.; Neuman, B.W.; et al. The Species Severe Acute Respiratory Syndrome-Related Coronavirus: Classifying 2019-NCoV and Naming It SARS-CoV-2. Nat. Microbiol. 2020, 5, 536-544, doi:10.1038/s41564-020-0695-z.

18. Heffron, J.; Mayer, B.K. Virus Isoelectric Point Estimation: Theories and Methods. Appl. Environ. Microbiol. 2021, 87, e02319-20, doi:10.1128/AEM.02319-20.

19. Scheller, C.; Krebs, F.; Minkner, R.; Astner, I.; Gil-Moles, M.; Wätzig, H. Physicochemical Properties of SARS-CoV-2 for Drug Targeting, Virus Inactivation and Attenuation, Vaccine Formulation and Quality Control. Electrophoresis 2020, 41, 1137-1151, doi:https://doi.org/10.1002/elps.202000121.

20. Pawłowski, P.H. Additional Positive Electric Residues in the Crucial Spike Glycoprotein S Regions of the New SARS-CoV-2 Variants. Infect. Drug Resist. 2021, 14, 5099-5105, doi:10.2147/IDR.S342068. 
medRxiv preprint doi: https://doi.org/10.1101/2022.01.05.22268808; this version posted January 6, 2022. The copyright holder for this preprint (which was not certified by peer review) is the author/funder, who has granted medRxiv a license to display the preprint in perpetuity. All rights reserved. No reuse allowed without permission.

21. Tsai, P.P.; Schreuder-Gibson, H.; Gibson, P. Different Electrostatic Methods for Making Electret Filters. J. Electrost. 2002, 54, 333-341, doi:10.1016/S0304-3886(01)00160-7.

22. Wang, J.; Rychkov, D.; Gerhard, R. Chemical Modification with Orthophosphoric Acid Enhances Surface-Charge Stability on Polypropylene Electrets. Appl. Phys. Lett. 2017, 110, 192901, doi:10.1063/1.4983348. 